\title{
Development Potential Assessment of Chuvash Republic Electrical Engineering Industry
}

\author{
Artem Sergeevich Evseev \\ Chair of State and Municipal Management and Regional \\ Economy \\ I.N. Ulianov Chuvash State University \\ Cheboksary, Russia \\ sumerh@mail.ru
}

\author{
Nataliya Vitalevna Morozova \\ Chair of State and Municipal Management and Regional \\ Economy \\ I.N. Ulianov Chuvash State University \\ Cheboksary, Russia \\ morozovanw@mail.ru
}

\author{
Alevtina Grigorevna Kulagina \\ Chair of Actuarial and Financial Mathematics \\ I.N. Ulianov Chuvash State University \\ Cheboksary, Russia \\ agku168@bk.ru
}

\begin{abstract}
The relevance of the research is due to the fact that there is a lack of scientific knowledge in determining the development potential of the Chuvash Republic electrical engineering industry, which will help to form a clearer view of the performance of electrical engineering industry enterprises as participants in regional innovation processes. The purpose of this article is to assess the development potential of the regional electrical engineering industry. The leading approach to the research is an integrated one, and the method is a statistical and economic one, which allows to give a comprehensive description of the electrical engineering industry development in modern conditions. As a result of the analysis, we can state that we have assessed and substantiated the development potential of the region's electrical engineering industry: the advanced enterprises of Chuvash Republic electrical engineering cluster created a reserve expressed in the use of modern technological processes and international quality management standards in industries, however, a certain portion of opportunities is in the form of maximizing the implementation of human capital abilities, shaping the economy knowledge, is still not finding proper application, waiting for arrangements allowing it to realize the development potential of the industry.
\end{abstract}

Keywords: electrical engineering industry, potential assessment, regional development, cluster, government regulation, knowledge economy

\section{INTRODUCTION}

In a market economy, various ways of attracting resources The relevance of the research was predetermined by the fact that the enterprises of the electrotechnical engineering cluster, having a solid research base and highly qualified staff, are inferior in economic indicators to the world leaders in this industry. Currently, the electrical engineering industry of the region [1] can be characterized as innovative [2], however, there are factors that restrain its development potential. Despite the long-term implementation of measures aimed at strengthening the position in the global market, as well as other work carried out by joint efforts of the state and firms in order to increase the level of competitiveness [3] of domestic companies in the field of electrical engineering, regional cluster enterprises $[4 ; 5]$ cannot accelerate the development of the industry and reach the level of performance of organizations such as Siemens, Alstom and General Electric. The development potential assessment of the industry is one of the first steps necessary to determine its development status.

Based on the foregoing, the purpose of the research is to assess and justify the development potential of the region's electrical engineering industry in the modern economy.

In the framework of the research, it we solved following tasks: identifying problems in the development of the region's electrical engineering industry in modern market conditions; analysis of internal and external environment in the industry market; analysis of market-forming factors of the high-tech equipment market; description of difficulties in entering into the market of regional manufacturers of electrical engineering products; substantiation of the need for changes aimed at improving the processes of electrical engineering cluster enterprises development management.

\section{METHODS}

The methodological basis of the research is an integrated approach. In the research process, the following methods were 
Chuvash Republic; NPO "Venture Investment Fund of the Chuvash Republic"; PJSC "Development Corporation of the Chuvash Republic".

The enterprises of the electrical engineering cluster employ 15.303 people (99.4\% compared to the first half of 2018), which is one fifth of the number of manufacturing enterprises employees.

For the first half of 2019, the turnover of organizations in the electrical engineering industry amounted to 21.590.4 million rubles (94\% compared to the first half of 2018) - this is $7.1 \%$ of the turnover of organizations of all types of economic activity of the Chuvash Republic, and the index of production of electrical engineering products decreased by one eighth compared to the corresponding period of 2018 .

The volume of shipped goods of its own production, work and services performed on its own by organizations of the electrical engineering industry amounted to 17832.7 million rubles (96.2\% compared to the first half of 2018) -this is almost one seventh of the volume of shipped goods, work and services of organizations of all types of economic activities of the Chuvash Republic.

The data on the balanced financial result in the Chuvash Republic electrical engineering industry in January-May 2019 are given in TABLE I. The rate of change in the balanced financial result of the reporting period compared to the corresponding period of the previous year is calculated for a comparable circle of organizations; taking into account the adjustment of the data of the corresponding period of the previous year, based on changes in accounting policies, legislative acts in accordance with the accounting methodology.

TABLE I. BALANCED FINANCIAL RESULTS IN JANUARY-MAY 2019

\begin{tabular}{|c|c|c|c|c|c|c|}
\hline \multirow{2}{*}{$\begin{array}{l}\text { Type of } \\
\text { economic } \\
\text { activity }\end{array}$} & \multicolumn{2}{|c|}{$\begin{array}{l}\text { Balance of profit } \\
(+) \text { and loss }(-)\end{array}$} & \multirow{2}{*}{$\begin{array}{c}\text { Amount } \\
\text { of profit, } \\
\text { million } \\
\text { rubles }\end{array}$} & \multirow{2}{*}{$\begin{array}{c}\text { The share of } \\
\text { profitable } \\
\text { organizations in } \\
\text { the total number } \\
\text { of } \\
\text { organizations, \% }\end{array}$} & \multirow{2}{*}{$\begin{array}{c}\text { Amount } \\
\text { of loss, } \\
\text { million } \\
\text { rubles }\end{array}$} & \multirow{2}{*}{$\begin{array}{c}\text { The share of } \\
\text { unprofitable } \\
\text { organizations } \\
\text { in the total } \\
\text { number of } \\
\text { organizations } \\
, \%\end{array}$} \\
\hline & $\begin{array}{c}\text { million } \\
\text { rubles }\end{array}$ & $\begin{array}{c}\% \text { by } \\
\text { January- } \\
\text { May } 2018\end{array}$ & & & & \\
\hline Total & 40788.1 & in 8.4 & 42042.2 & 69.1 & 1254.0 & 30.9 \\
\hline \multicolumn{7}{|l|}{ including: } \\
\hline $\begin{array}{c}\text { manufacturin } \\
\mathrm{g} \text { industries }\end{array}$ & 23839.8 & in 5.6 & 24564.0 & 68.6 & 724.1 & 31.4 \\
\hline \multicolumn{7}{|l|}{ of them: } \\
\hline $\begin{array}{c}\text { manufacture } \\
\text { of computers, } \\
\text { electronic and } \\
\text { optical } \\
\text { products }\end{array}$ & 266.1 & 91.0 & - & 83.3 & - & 16.7 \\
\hline $\begin{array}{c}\text { manufacture } \\
\text { of electrical } \\
\text { equipment }\end{array}$ & 364.7 & 20.4 & 788.7 & 60.9 & 424.0 & 39.1 \\
\hline
\end{tabular}

Indices of goods producers prices in the Chuvash Republic electrical engineering industry are shown in TABLE II. competitive advantages $[7 ; 8]$ in the field of electrical engineering: NPO Association "Innovative Territorial Electrical Engineering Cluster of the Chuvash Republic", Regional Engineering Center of the Chuvash Republic; Center for certification, standardization and testing of the Chuvash Republic; Academy of Electrical Engineering Sciences of the 
TABLE II. ELECTRICAL ENGINEERING PRODUCER PRICE INDICES IN 2014-2019

\begin{tabular}{|l|l|l|l|l|l|l|}
\hline $\begin{array}{l}\text { Type of economic } \\
\text { activity }\end{array}$ & $\mathbf{2 0 1 4}$ & $\mathbf{2 0 1 5}$ & $\mathbf{2 0 1 6}$ & $\mathbf{2 0 1 7}$ & $\mathbf{2 0 1 8}$ & $\begin{array}{c}\text { First } \\
\text { half of } \\
\mathbf{2 0 1 9}\end{array}$ \\
\hline $\begin{array}{l}\text { Production of } \\
\text { industrial goods, } \\
\% \text { to the previous } \\
\text { year }\end{array}$ & 106.5 & 113.5 & 107.6 & 103.6 & 104.7 & 100.2 \\
\hline $\begin{array}{l}\text { Manufacturing, \% } \\
\text { to the previous } \\
\text { year of }\end{array}$ & 107.1 & 114.2 & 107.7 & 103.5 & 104.6 & 105.8 \\
\hline $\begin{array}{l}\text { Production and } \\
\text { computers, } \\
\text { electronic } \\
\text { optical products, } \\
\% \text { to the previous } \\
\text { year }\end{array}$ & 99.2 & 110.9 & 105.7 & 104.0 & 101.3 & 105.6 \\
\hline $\begin{array}{l}\text { Production of } \\
\text { electrical } \\
\text { equipment, to } \\
\text { the previous year }\end{array}$ & 104.8 & 114.3 & 111.0 & 101.3 & 101.6 & 101.5 \\
\hline
\end{tabular}

To determine the influence of the external environment on the development of the industry, a PEST analysis was carried out (TABLE III).

The conducted PEST analysis indicates that the electrical engineering industry of Chuvash Republic is influenced by external factors that are reflected in the work of enterprises of the entire cluster, especially in its production indicators. It was revealed that using technological innovative solutions [9] it is possible to improve the quality of products and shorten the payback period. And also that a risk-based approach contributes to the intensification of production.

TABLE III. PEST ANALYSIS OF CHUVASH REPUBLIC ELECTRICAL ENGINEERING INDUSTRY

\begin{tabular}{|c|c|}
\hline Political & Economic \\
\hline $\begin{array}{l}\text { The lack of significant results in } \\
\text { the process of interaction of } \\
\text { economic agents involved in the } \\
\text { development of the electrical } \\
\text { engineering industry. }\end{array}$ & $\begin{array}{l}\text { The complexity of pricing policies at } \\
\text { the company level, as well as the } \\
\text { volatility of the price level. }\end{array}$ \\
\hline $\begin{array}{l}\text { Preferential tax conditions for } \\
\text { the accelerated development of } \\
\text { the industry. }\end{array}$ & Long payback period. \\
\hline $\begin{array}{l}\text { Difficulty in choosing an } \\
\text { effective industry development } \\
\text { strategy. }\end{array}$ & $\begin{array}{l}\text { Lack of experience with staff in } \\
\text { solving some problems. }\end{array}$ \\
\hline $\begin{array}{c}\text { Social } \\
\end{array}$ & Technological \\
\hline $\begin{array}{l}\text { Difficulty in regulating } \\
\text { legislative measures to restrict } \\
\text { civilians in the context of } \\
\text { technological change. }\end{array}$ & $\begin{array}{l}\text { Risk-oriented thinking }- \text { the } \\
\text { implementation of risk management } \\
\text { and control measures. }\end{array}$ \\
\hline $\begin{array}{l}\text { Inadequacy of main social mass } \\
\text { to technological changes. }\end{array}$ & $\begin{array}{l}\text { Technical and technological } \\
\text { modernization of production. }\end{array}$ \\
\hline $\begin{array}{l}\text { A hard-to-see perspective of the } \\
\text { emerging digital world. }\end{array}$ & $\begin{array}{l}\text { Difficulty in regulating legislative } \\
\text { measures to struggle the violation of } \\
\text { intellectual property rights. }\end{array}$ \\
\hline
\end{tabular}

The SWOT analysis shows that the region has accumulated significant potential for the development of the high-tech electrical engineering products market, but it still cannot be properly implemented (TABLE IV).
TABLE IV. SWOT ANALYSIS OF CHUVASH REPUBLIC ELECTRICAL ENGINEERING INDUSTRY

\begin{tabular}{|l|l|}
\hline \multicolumn{1}{|c|}{ Strengths } & \multicolumn{1}{|c|}{ Weaknesses } \\
\hline Good engineering base. & $\begin{array}{l}\text { Not enough initiative of economic } \\
\text { agents for high results in the } \\
\text { industry. }\end{array}$ \\
\hline $\begin{array}{l}\text { Developed logistics system. } \\
\text { Opportunities }\end{array}$ & Low level of salaries. \\
\hline $\begin{array}{l}\text { Close cooperation of universities } \\
\text { and } \begin{array}{l}\text { training centers with } \\
\text { enterprises of the electrical } \\
\text { engineering cluster. }\end{array}\end{array}$ & $\begin{array}{l}\text { Gradual, and sometimes latent, } \\
\text { management standards. }\end{array}$ \\
\hline $\begin{array}{l}\text { Improving the conditions in } \\
\text { quaternary sector of the economy. }\end{array}$ & $\begin{array}{l}\text { The emergence of new players in } \\
\text { the market. }\end{array}$ \\
\hline $\begin{array}{l}\text { Improving the system of } \\
\text { educational standards. }\end{array}$ & Threat from suppliers. \\
\hline $\begin{array}{l}\text { Increase of the share of exported } \\
\text { products. }\end{array}$ & The emergence of substitute goods. \\
\hline $\begin{array}{l}\text { The gradual transition of the state } \\
\text { economy to the knowledge } \\
\text { economy. }\end{array}$ & Instability of the price level. \\
\hline $\begin{array}{l}\text { State support for industry } \\
\text { enterprises. }\end{array}$ & The imposing new sanctions. \\
\hline
\end{tabular}

Thus, on the basis of the analysis it can be given the following assessment of the development potential of the Chuvash Republic electrical engineering industry.

1. The economy of Chuvash Republic is saturated with innovative changes in production processes. For example, high-tech equipment is used to simplify the production process and shorten the duration of the product cycle.

2. Transformational and transactional costs have a significant impact on the slowdown in the production of electrical engineering products.

3. There is a lag of the enterprises of the regional electrical engineering cluster in many economic indicators from the global leading companies for the production of electrical engineering products of different directions. Developing a strategy to increase the competitiveness of the region's electrical engineering cluster enterprises in the global market.

4. The subtle presence of the state in the formation of the advanced electrical engineering cluster of the region. Regional programs are implemented using funds from extra budgetary sources.

5. Low rates of intensification and extensification of production. An insignificant part of the enterprises of the electrical engineering cluster expands production capacities and realizes the reorganization of production.

6. Only some organizations in the electrical engineering industry of the region carry out crisis management. The insignificant diversification of production creates factors for the development of the crisis state of the company in particular and the industry as a whole.

7. Low interest of economic agents in the accelerated development of the electrical engineering industry. Insufficient initiative of participants in the development of the 
chosen strategy, and assigned tasks contribute to the continuous qualitative development of industry enterprises [21], aimed at advancing the economic indicators of competitors not only in the short, but also in the long term.

Also in the Chuvash Republic there is close cooperation between the enterprises of the electrical engineering cluster and educational institutions [22] (research and educational centers, universities, centers for advanced training) aimed at creating high-quality human capital and continuing education of employees.

\section{CONCLUSION}

The following assessment of the development potential of the Chuvash Republic electrical engineering industry is given and justified.

1. In the electrical engineering industry of the Chuvash Republic, innovative changes are taking place in production processes that shorten the production cycle and improve its quality.

2. It is traced the influence of transformational and transactional costs on the development, production and sale of electrical engineering products.

3. Domestic manufacturers of electrical engineering products are guided by world leaders in this field.

4. The subtle presence of the state in the formation of the advanced electrical engineering cluster of the region.

5. The low pace of expansion of production capacities of enterprises in the electrical engineering industry.

6. Low diversification of production, suppliers and risks.

7. The low interest of economic agents in the accelerated development of the electrical engineering industry.

8. Close cooperation of regional educational institutions and enterprises contributes to the formation of highly skilled workers.

9. There is an expansion of the circle of countriesimporters of products.

10. The relative stagnation of the venture capital business.

11. Gradual implementation by enterprises of a quality management system.

In theoretical terms, the results of this research can help with its use in the compilation and improvement of strategies and programs for the development of the electrical engineering industry in the region. In practical terms, it can be useful for economic agents associated with the electrical engineering industry, for example, when implementing plans and making decisions in strategic planning.

\section{REFERENCES}

[1] S. J. Lee, E. H. Lee, and D. S. Oh, "Establishing the innovation platform for the sustainable regional development: Tech-valley project in sejong city", Korea, World Technopolis Review, 2017, no. 6 (1), pp. 75-86. 
[13] R. Njos and S. E. Jakobsen, "Cluster policy and regional development: Scale, scope and renewal", Regional Studies, Regional Science, 2016, no. 3 (1), pp. 146-169.

[2] Y. Rianto, M. Zulhamdani, C. S. Laksani, and D. Prihadyanti, "Innovation system based industrial cluster development: a comparative study of industrial cluster in Indonesia and some Asian countries", 6th Asialics International Conference, Hong Kong, 2009, 31 p.

[3] N. V. Tumalanov, E. N. Tumalanov, I. N. Urusova, V. V. Ivanov, N. V. Morozova, and E. A. Antonovskaya, "Competitive opportunities of regional producers on growing markets of innovative goods", Man in India, 2017, no. 97 (14), pp. 283-289.

[4] E. Salvador, I. Mariotti and F. Conicella, "Science park or innovation cluster? Similarities and differences in physical and virtual firms' agglomeration phenomena", International Journal of Entrepreneurial Behavior and Research, 2013, no. 19 (6), pp. 656-674.

[5] M. Delgado, Michael E. Porter, and S. Stern, "Defining Clusters of Related Industries", Journal of Economic Geography, 2016, vol. 16:1, pp. $1-38$.

[6] R. M. Grant, "Contemporary strategy analysis", New York: Free Press, 1991, $518 \mathrm{p}$

[7] Rodriguez-Clare Andres, "Clusters and comparative advantage: Implications for industrial policy", Journal of Development Economics, 2007 , no. 82 , pp. $43-57$.

[8] G. Spencer Gregory, T. Vinodrai, M. Gertler, and D. Wolfe, "Do Clusters Make a Difference? Defining and Assessing their Economic Performance", Regional Studies, 2010, no. 4:6, pp. 697-715.

[9] L. Hilty and B. Aebischer, "ICT innovations for sustainability. Heidelberg", New York, Dordrecht, London: Springer, 2015, 470 p.

[10] Maine, Elicia and Lubik, Sarah and Garnsey, Elizabeth, "Value Creation Strategies for Science-Based Business: A Study of Advanced Materials Ventures", Innovation: Management, Policy and Practice, 2013, no. 15 (1), pp. 35-51. DOI: 10.5172/impp.2013.15.1.35.

[11] Zott, Christoph and Amit, Raphael, "Business Model Design and the Performance of Entrepreneurial Firms", Organization Science, 2007, vol. 18, no. 2, pp. 181-189. DOI: 10.1287/orsc.1060.0232.

[12] L. Jeng and P. Wells, "The Determinants of Venture Funding: Evidence across Countries", Journal of Corporate Finance, 2000, no. 6 (1), pp. 241-289.

[14] P. Grindley, David C. Mowery, and B. Silverman, "SEMATECH and Collaborative Research: Lessons in the Design of High-Technology Consortia", Journal of Policy Analysis and Management, 1994, no. 13.4, pp. 723-758.

[15] M. Negoita, "To Hide or Not to Hide? The Advanced Technology Program and the Future of U.S. Civilian Technology Policy", In Fred L. Block and Matthew R. Keller (eds.) State of Innovation: the U.S. Government's Role in Technology Development, Boulder, CO Paradigm Publishers, 2011, pp. 77-95.

[16] M.E. Porter, "Competitive Advantage: Creating and sustaining competitive advantage", New York: Free Press, 1985, 592 p.

[17] Y. L. Lai, M. S. Hsu, F. J. Lin, Y. M. Chen and Y. H. Lin, "The effects of industry cluster knowledge management on innovation performance", Journal of Business Research, 2014, no. 67 (5), pp. 734-739.

[18] D. Yoon, "The regional-innovation cluster policy for R\&D efficiency and the creative economy: With focus on daedeok innopolis", Journal of Science and Technology Policy Management, 2017, no. 8 (2), pp. 206226.

[19] M. Storper, "Keys to the City: How Economics, Institutions, Social Interaction, and Politics Shape Development", Princeton University Press: Princeton, NJ, 2013, 288 p.

[20] I. P. Danilov, E. A. Ilyina, T. I. Ladykova, and N. V. Morozova, "State policy of staffing of global reindustrialization of national economy", Journal of Advanced Research in Law and Economics, 2017, no. 8 (2), pp. 18-22.

[21] L. Souchon, B. Aebischer, J. Roturier, and F.Flipo, "Infrastructure of information society and its energy demand", European Council for an Energy Efficient Economy Summer Studies Proceedings, 2007, pp. $1215-1225$.

[22] M. L. Walshok, "Expanding Roles for Research Universities in Economic Development", New Directions for Higher Education, 1997, pp. 17-26. 